\title{
PENGARUH INKLUSI KEUANGAN DAN LITERASI KEUANGAN TERHADAP KINERJA UMKM DI KECAMATAN MOYO UTARA
}

\author{
Wira Iko Putri Yanti \\ Fakultas Ekonomi dan Bisnis, Jurusan Manajemen \\ Universitas Teknologi Sumbawa \\ e-mail: wiraikoputriyanti41@gmail.com
}

\begin{abstract}
Abstrak
Diterima

Penelitian ini bertujuan untuk mengetahui pengaruh Inklusi keuangan dan literasi

Bulan Juli 2019 keuangan terhadap kinerja UMKM. Penelitian ini menggunakan jenis penelitian Kuantitatif Asosiatif. Metode pengumpulan data dilakukan dengan membagikan kuesioner pada 102 responden yaitu pengusaha UMKM di Kecamatan Moyo Utara.

Diterbitkan Teknik pengambilan sampel menggunakan probability sampling dan sampling jenuh.

Bulan Juli 2019 Analisis data yang digunakan yaitu analisis regresi linear berganda. Berdasarkan hasil penelitian dapat disimpulkan bahwa kedua variabel bebas yaitu inklusi keuangan dan

Keyword: literasi keuangan memiliki pengaruh positif dan signifikan terhadap kinerja UMKM.
\end{abstract}

Inklusi Keuangan,

Literasi

Keuangan dan

Kinerja UMKM

\section{PENDAHULUAN}

Lembaga keuangan seperti bank maupun non bank berperan penting untuk mendukung perekonomian setiap masyarakat, baik masyarakat berpenghasilan besar maupun kecil untuk mendukung usahanya, dan salah satu permasalahan yang di alami hampir semua negara, termasuk Indonesia adalah masalah kemiskinan. Di Indonesia berbagai seminar dan pertemuan telah dilakukan untuk mengurangi kemiskinan, salah satunya dengan memudahkan masyarakat untuk mengakses lembaga keuangan untuk semua kalangan (Amalia dalam Laila, 2017). Keuangan inklusif adalah segala upaya yang dilakukan untuk menghapus semua yang menjadi hambatan masyarakat untuk menggunakan jasa keuangan, yang dimana inklusi keuangan juga merupakan strategi nasional untuk mendorong pertumbuhan ekonomi dengan mengurangi kemiskinan, pemerataan pendapatan dan stabilitas sistem keuangan. Dalam beberapa penelitian yang dilakukan oleh bank dunia di berbagai negara mendapatkan bahwa keterlibatan inklusi keuangan berperan penting dalam mengentas kemiskinan dan mendorong pertumbuhan ekonomi (Muhadjir et al , 2015).

Hambatan masyarakat dalam mengakses lembaga keuangan adalah tingginya unbankble (tidak memenuhi persyaratan pinjaman bank) yang disebabkan oleh kesenjangan kemiskinan, rendahnya pembiayaan UMKM, tingginya suku bunga kredit mikro, kurangnya kemampuan manajemen UMKM, dan terbatasnya saluran distribusi jasa keuangan, hal tersebut yang menjadikan penerapan inklusi keuangan penting
(Nengsih, 2015). Muhadjir et al (2015) mengatakan bahwa yang menjadi faktor usaha kecil lebih sering menggunakan modal sendiri, keluarga, kerabat, bahkan rentenir dalam menjalan usahanya karena rendah/sulitnya akses usaha kecil terhadap lembaga keuangan formal, dan tingkat suku bunga perbankan.

Akses yang lebih luas terhadap lembaga keuangan merupakan hal penting dalam meningkatkan partisipasi semua lapisan masyarakat dalam perekonomian. Di Indonesia pertumbuhan sektor keuangan saat ini masih kurang memadai dalam akses masyarakat terhadap layanan lembaga keuangan. Perluasan akses keuangan dan pemahaman tentang sektor keuangan perlu ditingkatkan agar dapat meningkatkan pertumbuhan ekonomi suatu negara. Dalam Rencana Pembangunan Jangka Menengah Nasional (RPJMN) 2015-2019, pemerintah telah menargetkan pertumbuhan ekonomi sebesar $8 \%$ pada tahun 2019, yaitu dengan meningkatkan akses pelayanan jasa keuangan bagi masyarakat dan Usaha Mikro Kecil dan Menengah (UMKM) untuk meningkatkan perekonomian yang inklusif dan adil (Peraturan Presiden, 2016). Inklusi keuangan merupakan komponen penting untuk mengurangi kesenjangan ekonomi. Inklusi keuangan adalah kondisi dimana setiap masyarakat mempunyai akses layanan keuangan formal yang berkualitas, aman, lancar, tepat waktu dan terjangkau serta sesuai dengan kemampuan dan kebutuhan masyarakat untuk meningkatkan kesejahteraan (Peraturan Presiden, 2016). 
Dalam menjalankan suatu usaha masyarakat membutuhkan modal, baik itu dari modal sendiri atau dengan meminjam di bank begitu pula dengan pengusaha UMKM, pemberian kredit untuk UMKM oleh lembaga keuangan sangat membantu pengusaha UMKMuntuk menjalankan usahanya. Pada tahun 2014 secara umum sekitar $36 \%$ penduduk dewasa di Indonesia sudah memiliki rekening, dan jumlah tersebut meningkat dibandingkan pada tahun 2011 jumlah penduduk yang memiliki rekening hanya $20 \%$. Hal ini menjukkan inklusi keuangan di Indonesia makin luas, akan tetapi masih ada kesenjangan antara penduduk yang berpendapatan rendah dalam memiliki rekening, dan jumlah perempuan yang memiliki rekening lebih sedikit dibandingkan dengan laki-laki, dimana hanya $37 \%$ perempuan yang memiliki rekening dari total penduduk perempuan di Indonesia (Peraturan Presiden, 2016).

UMKM memiliki peran yang cukup penting dalam meningkatkan pembangunan ekonomi suatu negara, tapi masih terhambat oleh beberapa persoalan, seperti lemahnya modal, produksi, pemasaran produk, dan sumber daya manusia (Irmawati dalam Laila, 2017). Dari tahun 1998-2018 jumlah konsumsi kredit UMKM belum mengalami perubahan yang signifikan, tingkat perubahannya belum bisa melebihi 20\% (Bank Indonesia, 2018). Semakin mudahnya akses perbankan akan memudahkan masyarakat maupun pelaku usaha dalam mengakses produk perbankan termasuk layanan kredit UMKM yang juga akan menambah jumlah penyalurannya (Linati, 2017).

Dalam menjalankan suatu usaha, seseorang juga harus memiliki kemampuan dan pengetahuan tentang keuangan untuk mengelola keuangannya secara efektik, karena itu literasi keuangan sangat penting bagi setiap pengusaha. Banyak penelitian yang mengatakan bahwa kemampuan seseorang dalam mengenali dan mengakses lembaga keuangan akan mempengaruhi tingkat pertumbuhan perusahaannya (Dwitya, 2016).

Di Nusa Tenggara Barat pertumbuhan kredit UMKM mengalami penurunan dan berada di bawah tren pertumbuhan total kredit sejak 2012 sampai 2013, hal tersebut menunjukan akses atau konsumsi masyarakat pengusaha UMKM terhadap lembaga keuangan atau perbankan menurun yang bisa disebabkan oleh rendahnya pertumbuhan UMKM yang memenuhi persyaratan pinjaman bank. Namun pada 2014 peran lembaga keuangan perbankan dalam mendorong perkembangan UMKM semakin meningkat, dengan besar kredit yang disalurkan mencapai $\mathrm{Rp} \mathrm{6,75}$ triliun, jumlah tersebut lebih banyak di bandingkan tahun sebelumnya yang sebesar Rp 6,60 triliun, dan pada 2018 jumlah kredit yang di salurkan oleh bank umum mencapai 10,99 triliun.Pemerintah juga membentuk program Kredit Usaha Rakyat untuk membantu UMKM dalam permodalan dan menjalankan usaha yang produktif danyang mengalami kesulitan dalam mengajukan pinjaman ke bank(Bank Indonesia, 2018).

Provinsi Nusa Tenggara Barat merupakan provinsi yang menduduki peringkat kedua terendah dalam skala nasional, dengan tingkat literasi keuangansebesar $21,45 \%$. Hal ini memperlihatkan bahwa tingkat literasi keuanganProvinsi NTB tergolong rendah (Bank Indonesia 2016).Di Sumbawa terdapat banyak UMKM yang berpotensi dan menjanjikan untuk di jalankan, tapi masih banyak UMKM tersebut yang terkendala oleh modal, pemasaran maupun SDM, salah satunya di bagian Moyo Utara. Pada Januari 2017 jumlah UMKM di Moyo Utara mencapai 102 UMKM, dimana sebagian umkm tersebut dijalankan oleh perempuan. Moyo Utara merupakan salah satu Kecamtan di Sumbawa yang memiliki UMKM terbanyak di Sumbawa yang dijalankan oleh perempuan, serta jenis produknya yang beragam, seperti tenun kain, permen susu, alat kesenian tradisional,ikan kering, jajan kering, pembuatan krupuk dan kripik dimana produk tersebut dibuat sendiri oleh pengusaha UMKM. Dengan adanya UMKM tersebut menjadi peluang masyarakat untuk mengembangkan potensi diri dan mengenalkan produk yang ada di Sumbawa, produk tersebut juga bisa menjadi daya tarik dan oleh-oleh dari Sumbawa.

Pertumbuhan UMKM di Sumbawa memberikan pengaruh terhadap pertumbuhan ekonomi masyarakat di Sumbawa karena UMKM memiliki kesempatan usaha yang luas yang berada di berbagai sektor ekonomi, tapi para pengusaha UMKM di Sumbawa masih kesulitan mengembangkan usaha mereka karena terkendala modal (Sudiarti et al, 2017). Irmawati (2013) mengatakan permasalahan utama yang dihadapi UMKM adalah masalah permodalan dan pemasaran, dan salah satu cara yang dapat dilakukan untuk mengatasi masalah tersebut adalah dengan menerapkan inklusi keuangan. Selain itu Anggraeni (2015) juga mengatakan bahwa literasi keuangan dapat membantu pelaku usaha terkait pengelolaan usaha yang dimulai dari anggaran, perencanaan simpanan dana usaha, serta pengetahuan dasar atas keuangan untuk mencapai tujuan keuangan.

Kesulitan keuangan bukan hanya disebabkan oleh rendahnya pendapatan saja,tetapi kesulitan keuangan juga dapat muncul jika terjadi kesalahan dalam pengelolaan keuangan seperti kesalahan penggunaan kredit, tidak adanya perencanaan keuangan dan tidak memiliki tabungan (Akmal, 2016). Pengetahuan pengusaha UMKM mengenai literasi keuangan dalam 
menjalankan usahanya sangat penting dan menjadi dasar untuk meningkatkan kinerja UMKM. Rika (2016) juga mengatakan bahwa selain edukasi, kemudahan dalam memperoleh dana/kredit sangat penting bagi masyarakat dalam menjalankan UMKM. Dari hal tersebut, peneliti mengajukan judul penilitian "Pengaruh Inklusi Keuangan dan Litersi Keuangan Terhadap Kinerja UMKMDi Moyo Utara".

\section{Rumusan Masalah}

1. Bagaimana pengaruh inklusi keuangan terhadap kinerja UMKM di Kecamatan Moyo Utara?

2. Bagaimana pengaruh literasi keuangan terhadap kinerja UMKM di Kecamatan Moyo Utara?

\section{Hipotesis Penelitian}

- $\mathrm{H}_{1}$ : inklusi keuangan berpengaruh signifikan terhadap KInerja UMKM

- $\mathrm{H}_{2}$ : Literasi keuangan berpengaruh signifikan terhadap kinerja UMKM

\section{STUDY PUSTAKA}

\section{Inklusi Keuangan}

Inklusi Keuangan adalah suatu kegiatan menyeluruh yang bertujuan untuk menghilangkan segala bentuk hambatan baik dalam bentuk harga maupun non harga terhadap akses masyarakat dalam menggunakan atau memanfaatkan layanan jasa keuangan. Selain itu dalam Strategi Nasional Keuangan Inklusif Bank Indonesia (2014), keuangan inklusif didefinisikan sebagai hak setiap orang untuk memiliki akses dan layanan penuh dari lembaga keuangan secara tepat waktu, nyaman, informatif, dan terjangkau biayanya, dengan penghormatan penuh kepada harkat dan martabatnya. Layanan keuangan tersedia bagi seluruh segmen masyarakat, denganperhatian khusus kepada orang miskin, orang miskin produktif, dan penduduk didaerah terpencil (Bank Indonesia, 2014).

Indikator inklusi keuangan, yaitu :

a. Dimensi akses

Yaitu faktor yang digunakan untuk mengukur kemampuan penggunaan jasa keuangan agar dapat melihat potensi hal-hal yang menjadi hambatan dalam membuka dan menggunakan rekening bank, seperti bentuk fisik layanan jasa keuangan (kantor bank, ATM dll)

b. Dimensi penggunaan

Yaitu faktor yang digunakan untuk mengukur penggunaan jasa keuangan dan produk, seperti frekuinsi, waktu/lama penggunaan dan keteraturan.

c. Dimensi kualitas

Yaitu faktor yang digunakan untuk mengetahui ketersediaan produk dan jasa keuangan telah memenuhi kebutuhan pelanggan. d. Dimensi kesejahteraan

Yaitu faktor yang digunakan untuk mengukur dampak layanan keuangan terhadap tingkat kehidupan pengguna jasa.

\section{Literasi Keuangan}

Otoritas Jasa Keuangan (OJK) mendefinisikan literasi keuangan sebagai pengetahuan, keterampilan, dan keyakinan yang mempengaruhi sikap dan prilaku individu untuk meningkatkan kualitas pengambilan keputusan dan pengelolaan keuangan dalam rangka mencapai kesejahteraan. Menurut widayati (2010) literasi keuangan terjadi ketika seseorang memiliki keahlian atau kemampuan yang membuat orang tersebut mencapai tujuannya dengan memanfaatkan sumber daya yang ada. Literasi keuangan merupakan kemampuan atau pengetahuan seseorang dalam mengelola semua sumber daya keuangannya dengan efektif (Manurung, 2009:24). Sedangkan menurut Farah dan Sari dalam Galang (2017) literasi keuangan merupakan kemampuan untuk mempertimbangkan dan membuat suatu keputusan terkain dengan penggunaan uang, literasi keuangan berpengaruh secara langsung pada kesejahteraan seseorang.

Literasi keuangan merupakan faktor yang fundamental untuk pertumbuhan ekonomi dan kestabilitas keuangan bagi konsumen,penyedia jasa keungan dan pemerintah. Litersi keuangan yang baik akan menimbulkan keputusan pembelian yang mengedepankan kualitas, dan meminimalisir keputusan yang salah yang akan diambil terhadap isu ekonomi dan keuangan. Literasi keuangan yang baik akan memberikan informasi yang memadai tentang produk, pemahaman resiko pada pelanggan, serta literasi keuangan yang baik pada masyarakat akan meningkatkan pemasukan pajak bagi pemerintah untuk memaksimalkan pengembangan infrstruktur dan fasilitas pelayanan publik (Dwitya, 2016).

Indikator literasi keuangan, yaitu:

a. Pengetahuan umum keuangan

Yaitu berkaitan dengan pengetahuan dasar seseorang tentang cara mengatur keuangan yang dimilki secara pribadi, keluarga maupun usaha yang dijadikan sebagai acuan dalam mengelola keuangan. Kurangnya pengetahuan keuangan dapat menimbulkan kesalahan dalam mengambil keputusan untuk menabung, meminjam maupun berinvestasi (Chen and Volpe, 1998). Pengetahuan tentang keuangan sangat penting tidak hanya bagi individu saja tapi juga bagi perusahaan dan perekonomian, semakin tinggi pengetahuan keuangan seseorang, orang tersebut cenderung memilki perilaku keuangan yang bijak (Norma dan Meliza, 2013) 
b. Tabungan dan pinjaman

Tabungan yaitu simpanan uang seseorang dibank yang penarikannya hanya dapat dilakukan berdasarkan syarat-syarat yang telah disepakati (Widyaningsih, 2005:15). Menurut UU perbankan No 10 tahun 1998 tabungan merupakan simpanan nasabah yang penarikannya dapat dilakukan sewaktu waktu oleh nasabah serta sesuai dengan syarat-syarat yang telah disepakati. Tabungan adalah simpanan uang seseorang dari sebagian pendapatan yang tidak dikonsumsi melainkan disiapkan atau digunakan untuk kebutuhan di masa yang akan datang (Dwi Latifiana, 2017). Pinjaman merupakan kredit yang diberikan oleh kreditur kepada individu dengan tenggak waktu tertentu untuk pelunasannya kembali, bank merupakan lembaga yang menerima setoran dari individu atau badan tertentu dan membuat pinjaman atau kredit (Manurung, 2009:7). Pinjaman yaitu uang atau tagihan hutang yang harus dilunasi setelah jangaka waktu tertentu yang telah disepakati antara pihak peminjam dan pihak yang memberi pinjaman dengan pemberian bunga (Dendawijaya, 2009).

c. Asuransi

Yaitu salah satu bentuk pengendalian resiko yang dilakukan dengan cara mengalihkan resiko dari satu pihak ke pihak yang lain (Akmal dan Saputra, 2016).

d. Investasi

Yaitu menanamkan sejumlah uang (dana) disutu tempat dengan harapan uang tersebut dapat bertambah banyak dan menguntungkan (Istijanto, 2009). Menurut Haming (2010) invetasi merupakan pengeluaran dana pada masa sekarang dengan tujuan untuk mendapat keuntungan yang lebih besar dimasa yang akan datang. Invetasi merupakan menyimpan sejumlah uang atau aset yang dimilki yang disimpan untuk memperoleh keuntungan yang lebih dimasa yang akan datang (Dwi Latifiana, 2017).

\section{Kinerja UMKM}

Ali dalam Dwitya (2016) mengatakan bahwa kinerja UMKM dianalisis dengan menggunakan pendekatan yang didasarkan pada tiga asumsi, yaitu: 1). Pengukuran kinerja UMKM kerap sulit dilakukan secara kuantitatif, dikarenakan terbatasnya sumber daya (pemahaman keuangan dan tenaga kerja). 2). Pengukuran kinerja pada umumnya melihat indikator keuangan yang kompleks, sehingga hal ini tidak secara lengkap memperlihatkan kondisi aktual yang terjadi di bisnis tersebut. 3). Pengukuran kinerja yang kerap dipakai relatif hanya sesuai bila digunakan untuk perusahaan besar yang ter-struktur dalam manajemen perusahaannya. Dari hal tersebut maka JURNAL MANAJEMENDANEISNS digunakan pendekatan non cost performance measures yaitu pengukuran melalaui persepsi untuk mengukur tingkat kinerja UMKM, baik kinerja keuangan maupun non keuangan (Kaplan et al, 2005).

Indikator dari kinerja UMKM, yaitu :

a. Pertumbuhan usaha

Yaitu kemampuan suatu usaha dalam meningkatkan penjualan, keuntungan dan melakukan diversifikasi dalam lini produk. Menurut Dwitya (2016) pertumbuhan usaha dilihat melalui peningkatan penjualan suatu usaha dalam satu periode ke priode berikutnya, jika tingkat penjualan usaha tinggi/baik maka laba yang diperoleh juga meningkat.

b. Total pendapatan usaha

Total pendapatan usaha berasal dari kegiatan utama perusahaan, yaitu semua pendapatan yang di dapat dari selisih antara penerimaan dengan total biayadalam kurun waktu tertentu. Pendapatan dapat diklasifikasikan menjadi dua, yaitu pendapatan operasional (pendapatan dari hasil penjualan produk atau jasa yang meruapakan kegiatan utama suatu usaha) dan pendapatan non operasional, pendapatan non operasioanl merupakan pendapatan yang diperoleh diluar kegiatan utama perusahaan yang bersifat isidentil (pendapatan dari hasil penjualan surat berharga, penjualan aktiva tak berujud, bunga, sewa dan royalti).

c. Total order

Yaitu total pesanan produk yang dipesan atau akan di beli oleh konsumen. Menurut Dwitya (2016) order merupakan proses pembelian yang dilakukan oleh pembeli kepada penjual baik secara langsung maupun tidak (online).

d. Posisi kas usaha

Yaitu pencatatan keuangan usaha untuk mengetahui besar keuntungan yang didapat dalam usaha tersebut dan untuk mengetahui arus kas masuk dan arus kas keluar. Nominal arus kas bersih didapat dari mengurangi arus kas masuk dengan arus kas keluar. Jika arus kas bersih menunjukan angka positif, berarti perusahaan mengalami surplus atau memperoleh laba demikian pula sebaliknya.

\section{Kerangka Konseptual}

Berdasarkan landasan teori dan penelitian terdahulu maka dapat disusun suatu kerangka konseptual dalam penelitian ini seperti berikut:

Gambar 2.1

Kerangka Konseptual

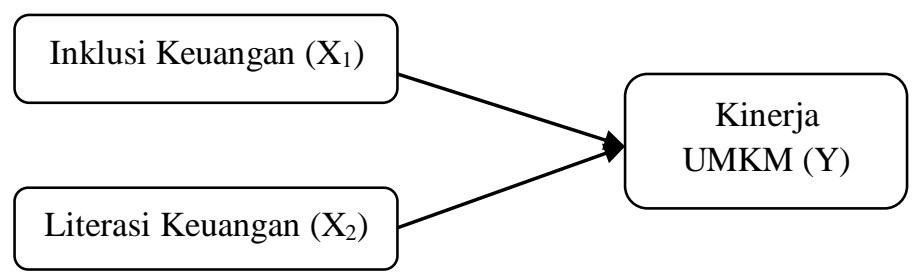




\section{Keterangan:}

$\underset{\text { variabel independen terhadap variabel dependen }}{\longrightarrow}$

Melalui kerangka berbikir diatas dapat dilihat bahwa variabel dependen $(\mathrm{Y})$ dalam penelitian ini yaitu kinerja UMKM sedangkan variabel independen $(\mathrm{X})$ yaitu inklusi keuangan dan literasi keuangan. Tujuan kerangka berfikir adalah untuk melihat pengaruh variabel independen terhadap variabel dependen.

\section{METODE PENELITIAN}

\section{Rancangan Penelitian}

Jenis penelitian yang digunakandalam penelitian ini adalah penelitian kuantitatif dengan menggunakan pendekatan asosiatif. Penelitian kuantitatif adalah penelitian yang memperoleh data berbentuk angka atau data kualitatif yang diangkakanatau data yang berbentuk angka pada analisis statistik. Penelitian asosiatif merupakan penelitian yang bertujuan untuk mengetahui pengaruh ataupun hubungan antara dua variabel atau lebih (Sugiyono, 2015). Penelitian ini mempunyai tingkatan tertinggi dibandingkan dengan deskriptif dan komparatif karena dengan penelitian ini dapat dibangun suatu teori yang dapat berfungsi untuk menjelaskan, meramalkan dan mengontrol suatu gejala. Ada 2 variabel di dalam penelitian ini yaitu variabel independen dan variabel dependen. Variabel independen yaitu inklusi keuangan $\left(\mathrm{X}_{1}\right)$, literasi keuangan $\left(\mathrm{X}_{2}\right)$, dan variabel dependen yaitu kinerja UMKM $(\mathrm{Y})$.

\section{Populasi dan Sampel}

Populasi yaitu kumpulan elemen yang menunjukkan ciri-ciri tertentu yang digunakan untuk membuat kesimpulan (Sanusi, 2011:87). Populasi dalam penelitian ini berjumlah 102 UMKM, populasi dari penelitian ini adalah para pengusaha UMKM di Moyo Utara. Dengan kriteria :UMKM di Moyo Utara yang terdaftar di Diskoperindak Sumbawa tahun 2017.

Sampel adalah bagiandari jumlah dan karateristik yang dimiliki oleh populasi tersebut. Bila populasi besar dan peneliti tidak mungkin mempelajari semua yang ada pada populasi, misalnya karna keterbatasan dana, tenaga, dan waktu, maka peneliti dapat menggunakan sampel yang diambil dari populasi itu (Sugiono, 2015:81). Metode penetuan sempel yang digunakan dalam penelitian ini yaitu metode probability sampling dengan cara sampling jenuh. Probability sampling adalah teknik pengambilan sampel yang semua JURNAL MANAJEMENDANBISNIS elemen populasi mempunyai peluang atau kesempatan untuk dipilih menjadi sampel. Sampling jenuh adalah teknik pengambilan sampel yang menjadikan semua anggota populasi sebagai sampel (Sugiyono, 2015:84-85).

\section{Pengumpulan Data}

Data yang diperoleh langsung dari sumber atau subjek penelitian. Sumber data primer adalah data yang diperoleh secara langsung dengan membagi kuisioner kepada responden.Data yang diperoleh secara tidak langsung melalui media cetak seperti buku, jurnal, katalog perusahaan, dan keterangan lain yang berhubungan dengan pokok penelitian. Dalam hal ini, sumber data sekunder adalah dokumentasi.

\section{Analisis Data \\ Uji Validitas dan Uji Reliabilitas \\ 1. Uji Validitas}

Uji validitas atau kesahihan adalah menujukan bahwa sejauh mana suatu alat ukur mampu mengukur apa yang ingin diukur. Menurut Imam Ghozali (2010) uji validitas digunakan untuk mengukur valid atau tidaknya suatu data kuesioner. Kuesioner dikatakan valid jika pertanyaan dalam kuesioner mampu untuk mengungkapkan suatu suatu yang akan diukur oleh kuesioner tersebut. Kriteria uji validitas:

- Apabila $r_{\text {hitung }}>r_{\text {tabel, }}$ maka item kuesioner tersebut valid.

- Apabila $\mathrm{r}_{\text {hitung }}<\mathrm{r}_{\text {tabel, }}$ maka item kuesioner tersebut tidak valid.

Tabel 3.1

Hasil Uji Validitas

\begin{tabular}{|l|l|l|l|l|}
\hline \multirow{4}{*}{ Variabel } & $\begin{array}{c}\text { Item } \\
\text { Pertany } \\
\text { aan }\end{array}$ & $\mathrm{r}_{\text {hitung }}$ & $\mathrm{r}_{\text {tabel }}$ & $\begin{array}{c}\text { Keter } \\
\text { angan }\end{array}$ \\
\hline $\begin{array}{l}\text { Inklusi } \\
\text { Keuangan } \\
\left(\mathrm{X}_{1}\right)\end{array}$ & IK1 & 0,562 & 0,361 & Valid \\
\cline { 2 - 5 } & IK2 & 0,449 & 0,361 & Valid \\
\cline { 2 - 5 } & IK3 & 0,378 & 0,361 & Valid \\
\cline { 2 - 5 } & IK4 & 0,592 & 0,361 & Valid \\
\cline { 2 - 5 } & IK5 & 0,610 & 0,361 & Valid \\
\cline { 2 - 5 } & IK6 & 0,648 & 0,361 & Valid \\
\cline { 2 - 5 } & IK7 & 0,456 & 0,361 & Valid \\
\cline { 2 - 5 } & IK8 & 0,455 & 0,361 & Valid \\
\cline { 2 - 5 } & IK9 & 0,572 & 0,361 & Valid \\
\cline { 2 - 5 } & IK10 & 0,489 & 0,361 & Valid \\
\hline \multirow{4}{*}{$\left.\begin{array}{l}\text { Kiterasi } \\
\text { Keuangan }\end{array}\right)$} & KL1 & 0,814 & 0,361 & Valid \\
\cline { 2 - 5 } & KL2 & 0,685 & 0,361 & Valid \\
\cline { 2 - 5 } & KL3 & 0,764 & 0,361 & Valid \\
\hline
\end{tabular}




\begin{tabular}{|l|l|l|l|l|}
\hline \multirow{4}{*}{} & KL4 & 0,846 & 0,361 & Valid \\
\cline { 2 - 5 } & KL5 & 0,756 & 0,361 & Valid \\
\cline { 2 - 5 } & KL6 & 0,388 & 0,361 & Valid \\
\cline { 2 - 5 } & KL7 & 0,471 & 0,361 & Valid \\
\cline { 2 - 5 } & KL8 & 0,362 & 0,361 & Valid \\
\cline { 2 - 5 } & KL9 & 0,426 & 0,361 & Valid \\
\cline { 2 - 5 } Kinerja & KL10 & 0,483 & 0,361 & Valid \\
\hline \multirow{5}{*}{ UKM (Y) } & UK1 & 0,571 & 0,361 & Valid \\
\cline { 2 - 5 } & UK2 & 0,473 & 0,361 & Valid \\
\cline { 2 - 5 } & UK3 & 0,724 & 0,361 & Valid \\
\cline { 2 - 5 } & UK4 & 0,618 & 0,361 & Valid \\
\cline { 2 - 5 } & UK5 & 0,624 & 0,361 & Valid \\
\cline { 2 - 5 } & UK6 & 0,481 & 0,361 & Valid \\
\cline { 2 - 5 } & UK7 & 0,379 & 0,361 & Valid \\
\cline { 2 - 5 } & UK8 & 0,637 & 0,361 & Valid \\
\hline
\end{tabular}

Sumber: Data diolah, 2019

\section{Uji Reliabilitas}

Uji reliabilitas digunakan untuk menunjukkan konsistensi hasil pengukuran alat pengukur yang digunakan oleh orang yang sama dalam waktu yang berbeda atau digunakan oleh orang yang berbeda dalam waktu yang bersamaan atau waktu yang berbeda (Sanusi, 2011:80). Uji reliabilitas merupakan suatu alat yang digunakan untuk mengukur suatu kuesioner yang merupakan indikator dari variabel (Siregar, 2017:55).

Adapun cara yang digunakan untuk menguji reliabilitas kuesioner dalam penelitian ini adalah menggunakan nilai koefisien Alpha Cronbach, yaitu:

- Apabila hasil koefisien Alpha> taraf signifikansi 60\% atau 0,6 maka kuesioner tersebut reliabel

- Apabila hasil koefisien Alpha< taraf signifikansi $60 \%$ atau 0,6 maka kuesioner tersebut tidak reliabel

Tabel 3.3

Hasil Uji Reliabilitas

\begin{tabular}{|l|c|c|c|}
\hline \multicolumn{1}{|c|}{ Variabel } & $\begin{array}{l}\text { Koefisien } \\
\text { alpha }\end{array}$ & $\begin{array}{l}\text { Taraf } \\
\text { signifikansi }\end{array}$ & Keterangan \\
\hline $\begin{array}{l}\text { Inklusi } \\
\text { Keuangan }\end{array}$ & 0,685 & 0,60 & Reliabel \\
\hline $\begin{array}{l}\text { Literasi } \\
\text { Keuangan }\end{array}$ & 0,806 & 0,60 & Reliabel \\
\hline $\begin{array}{l}\text { Kinerja } \\
\text { UMKM }\end{array}$ & 0,692 & 0,60 & Reliabel \\
\hline
\end{tabular}

Sumber: data diolah 2019

JURNAL MANAJEMEN DANBISNIS

\section{Uji Asumsi Klasik}

Menurut Sanusi (2011: 135) penggunaan uji asumsi klasik yaitu untuk memenuhi asumsiasumsi yang telah ditetapkan agar menghasilkan nilai koefisien yang tidak bias, cara untuk mendeteksi gejala-gejala tersebut diuraikan sebagai berikut :

1. Uji Normalitas

Uji normalitas bertujuan untuk menguji apakah dalam model regresi variabel terikat, variabel bebas atau keduanya mempunyai distribusi normal atau tidak. Pengujian normalitas dalam penelitian ini menggunakan bantuan program SPSS Statistic 16 Windows dengan statistik One Sample Kolmogrov Smirnov Test. Pengukuran yang digunakan adalah membandingkan nilai asymp. Sig (2-tailed) dengan nilai yang ditentukan sebesar $5 \%$. Apabila nilai asymp. Sig (2-tailed) lebih besar dari 0,05 maka dapat disimpulkan bahwa data tersebut berdistribusi normal. Hasil uji normalitas adalah sebagai berikut:

Tabel 4.5 Hasil Uji Normalitas

One-Sample Kolmogorov-Smirnov Test

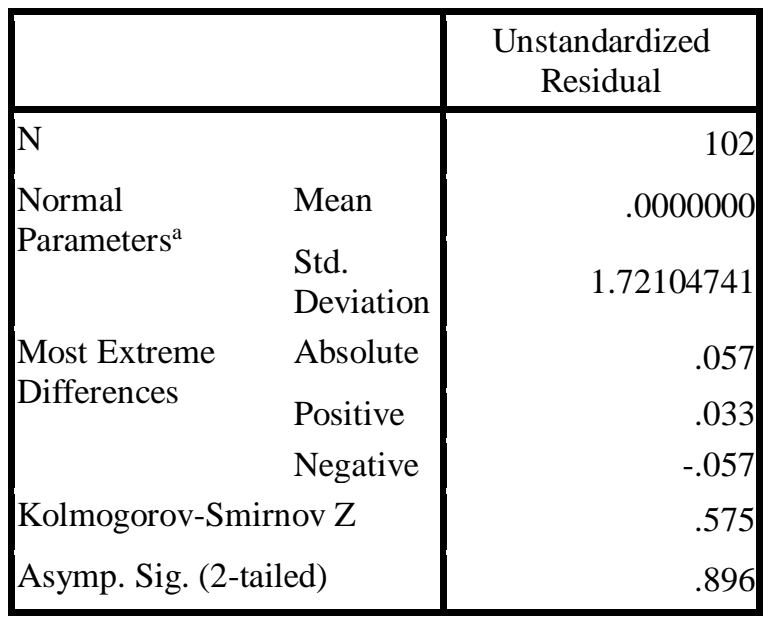

Sumber: data diolah 2019

Berdasarkan Tabel 4.5 hasil uji normalitas di atas diperoleh Asymp. Sig (2-tailed) sebesar 0,896 yang berarti lebih besar dari 0,05 , maka dapat disimpulkan bahwa data dalam penelitian ini berdistribusi normal.

2. Uji Multikolinearitas

Uji multikolinearitas bertujuan untuk menguji dalam regresi terdapat gejala kolerasi antar variabel bebas lainnya. Model regresi yang baik seharusnya tidak terjadi korelasi diantara variabel bebas. Pemeriksaan untuk mendeteksi gela multikolinearitas dilakukan dengan melihat nilai tolerance dan VIF (Variance Inflation Factor) yang dihitung menggunakan SPSS statistic 16 for window. Hasil uji multikolinearitas disajikan dalam tabel berikut: 
Tabel 4.6 Hasil Uji

Multikolinearitas

\begin{tabular}{|c|c|c|c|}
\hline Variabel & $\begin{array}{l}\text { Toleranc } \\
\mathrm{e}\end{array}$ & VIF & Keterangan \\
\hline $\begin{array}{c}\text { Inklusi } \\
\text { keuangan }\end{array}$ & 0,949 & 1,054 & $\begin{array}{l}\text { Tidak terjadi } \\
\text { multikolinea } \\
\text { ritas }\end{array}$ \\
\hline $\begin{array}{c}\text { Literasi } \\
\text { keuangan }\end{array}$ & 0,949 & 1,054 & $\begin{array}{l}\text { Tidak terjadi } \\
\text { multikolinea } \\
\text { ritas }\end{array}$ \\
\hline
\end{tabular}

Sumber: data diolah 2019

Tabel 4.6 diatas menunjukan bahwa variabel inklusi keuangan (X1) dengan nilai tolerance $0,949>0,1$ dan nilai VIF $1,054<$ 10, dan variabel literasi keuangan (X2) dengan nilai tolerance $0,949>0,1$ dan niali VIF $1,054<10$. Maka dapat disimpulkan bahwa semua variabel bebas tidak terjadi multikolinearitas.

3. Uji Heteroskedastisitas

Uji hesterokedastisitas bertujuan untuk menunjukan bahwa adanya varian variabel tidak sama untuk semua observasi. Untuk mendeteksi ada atau tidaknya hesterokedastisitas dalam penelitian ini menggunakan pengujian Glejser dengan syarat jika nilai Sig di atas 0,05 maka tidak terjadi hesterokedastisitas. Dalam pengujian hesterokedastisitas menggunakan bantuan SPSS statistic for windows 16. Hasil uji hesterokedastisitas dapat dilihat pada tabil berikut:

Tabel 4.7 Hasil Uji

Heteroskedastisitas

\begin{tabular}{|c|c|c|c|c|c|}
\hline \multirow[b]{2}{*}{ Model } & \multicolumn{2}{|c|}{$\begin{array}{c}\text { Unstandardiz } \\
\text { ed } \\
\text { Coefficients }\end{array}$} & \multirow{2}{*}{$\begin{array}{c}\text { Standardized } \\
\text { Coefficients } \\
\text { Beta }\end{array}$} & \multirow[b]{2}{*}{$\mathrm{t}$} & \multirow[b]{2}{*}{ Sig. } \\
\hline & B & $\begin{array}{c}\text { Std. } \\
\text { Error }\end{array}$ & & & \\
\hline 1 (Constant) & 2.171 & 1.762 & & 1.232 & .221 \\
\hline $\begin{array}{l}\text { INKLUSI } \\
\text { KEUANG } \\
\text { AN }\end{array}$ & -.042 & .053 & -.082 & -.801 & .425 \\
\hline $\begin{array}{l}\text { LITERAS } \\
\text { I } \\
\text { KEUANG } \\
\text { AN }\end{array}$ & .015 & .040 & .039 & .381 & .704 \\
\hline
\end{tabular}

Sumber: data diolah 2019

Dari tabel 4.7 menunjukan bahwa nialai signifikansi dari inklusi keuangan (X1) sebesar $0,425>0,05$, sedangkan nilai signifikansi dari literasi keuangan $(X 2)$ sebesar 0,704 > 0,05. Maka dapat disimpulkan bahwa dari kedua variabel bebas dalam penelitian ini tidak terindikasi hesterokedastisitas atau terjadinya homoskedastisitas.

\section{Analisis Regresi Linear Berganda}

Analisis regresi linear berganda digunakan untuk mengetahui pengaruh inklusi keuangan $\left(\mathrm{X}_{1}\right)$, literasi keuangan $\left(\mathrm{X}_{2}\right)$ terhadap kinerja UMKM (Y). Adapun persamaan yang digunakan dalam penelitian ini adalah sebagai berikut:

$$
Y=\alpha+b_{1} x_{1}+b_{2} x_{2}+e
$$

\section{Tabel 4.8 Hasil Analisis Regresi Linear Berganda}

\begin{tabular}{|c|c|c|c|c|c|}
\hline \multirow[b]{2}{*}{ Model } & \multicolumn{2}{|c|}{$\begin{array}{c}\text { Unstandardized } \\
\text { Coefficients }\end{array}$} & \multirow{2}{*}{\begin{tabular}{|c|}
$\begin{array}{c}\text { Standardized } \\
\text { Coefficients }\end{array}$ \\
Beta
\end{tabular}} & \multirow[b]{2}{*}{$\mathrm{T}$} & \multirow[b]{2}{*}{ Sig. } \\
\hline & B & $\begin{array}{l}\text { Std. } \\
\text { Error }\end{array}$ & & & \\
\hline 1 (Constant) & 1.486 & 3.424 & & 5.399 & .000 \\
\hline $\begin{array}{l}\text { Inklusi } \\
\text { Keuangan }\end{array}$ & .208 & .098 & .204 & 2.119 & .037 \\
\hline $\begin{array}{l}\text { Literasi } \\
\text { Keuangan }\end{array}$ & 189 & .077 & .235 & 2.441 & .016 \\
\hline
\end{tabular}

Sumber: hasil pengelolaan data SPSS 16.0

Berdasarkan hasil analisis regresi pada tabel 4.8 maka dapat diketahui persamaan regresi sebagai berukut:

$$
\mathrm{Y}=1,486+0,208 \mathrm{X}_{1}+0,189 \mathrm{X}_{2}+\mathrm{e}
$$

Hasil persamaan regresi berganda diatas dapat memberikan pengertian sebagai berikut:

a. Nilai konstanta sebesar 1,486 menunjukan bahwa ketika variabel independen yaitu inklusi keuangan dan literasi keuangan diasumsikan diabaikan, maka nilai kinerja UMKM (Y) sebesar 1,486

b. Nilai koefisien regresi variabel inklusi keuangan $\left(X_{1}\right)$ bernilai positif yaitu 0,208 menunjukan apabila nilai inklusi keuangan $\left(X_{1}\right)$ mengalami kenaikan satu satuan sementara variabel independen lainnya diasumsikan tetap, maka nilai inklusi keuangan akan meningkat sebesar 0,208.

c. Nilai koefisien regresi variabel literasi keuangan $\left(\mathrm{X}_{2}\right)$ bernilai positif yaitu 0,189 menunjukan apabila nilai literasi keuangan $\left(X_{2}\right)$ mengalami kenaikan satu satuan sementara variabel independen lainnya diasumsikan tetap, maka nilai literasi keuanganakan meningkat sebesar 0,189. 


\section{Uji Hipotesis}

1. Uji Parsial (Uji t)

Uji $t$ digunakan untuk menguji apakah pernyataan dalam hipotesis itu benar. Uji $t$ pada dasarnya menunjukan seberapa jauh pengaruh suatu variabel independen secara individual dalam menerangkan variabel dependen, pengujian menggunakan tingkat signifikansi 0,05 . Jika nilai sig. > 0,05 maka Ho di terima dan Ha ditolak sedangkan jika sig. < 0,05 maka Ho di ditolak dan $\mathrm{Ha}$ diterima, dari uji t dengan bantuan software SPSS for window versi 16 didapatkan hasil sebagai berikut:

a. Variabel Inklusi Keuangan

Berdasarkan tabel 4.8 di atas dapat dilihat bahwa nilai $t_{\text {hitung }}$ variabel inklusi keuangan sebesar 2,119, dimana thitung $>$ $t_{\text {tabel }}(2,119>1,984)$ dengan ini nilai signifikansi $0,037<0,05$. Maka Ho di tolak dan Ha diterima, sehingga dapat disimpulkan bahwa ada pengaruh yang signifikan antara inklusi keuangan dengan kinerja UMKM.

b. Variabel Literasi Keuangan

Berdasarkan tabel 4.8 di atas dapat dilihat

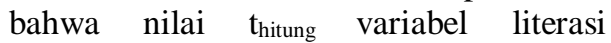
keuangan sebesar 2,441, dimana thitung $>$ $t_{\text {tabel }}(2,441>1,984)$ dengan ini nilai signifikansi $0,016<0,05$. Maka Ho di tolak dan Ha diterima, sehingga dapat disimpulkan bahwa ada pengaruh yang signifikan antara literasi keuangan dengan kinerja UMKM.

\section{PEMBAHASAN}

\section{Pengaruh Customer Relationship Management Terhadap Keputusan Pembelian}

Hasil pengujian yang disajikan pada Tabel 4.10 menunjukkan CRM $\left(\mathrm{X}_{1}\right)$ dengan nilai $t_{\text {hitung }} 6,032>t_{\text {tabel }} 1,984$ dengan nilai signifikansi $0,000<0,05$, artinya CRM berpengaruh signifikan terhadap keputusan pembelian. Hasil ini mendukung hipotesis bahwa CRM memengaruhi keputusan pembelian. Pengaruh dari CRM terhadap keputusan pembelian hasil analisis menunjukkan bahwa CRM berpengaruh positif dan signifikan terhadap keputusan pembelian. Hal ini menunjukkan bahwa CRM yang dipersepsi baik oleh pelanggan akan tercipta kedekatan antara pelanggan dengan perusahaan. Adanya CRM yang baik juga secara langsung membuat citra perusahaan menjadi terjaga dimana pelanggan akan melihat bahwa perusahaan memiliki reputasi yang terpercaya. Hal ini akan membuat pelanggan menjadi percaya dalam melakukan pembelian di perusahaan NSS tersebut karena merasakan adanya kedekatan dari pihak perusahaan.

Menurut Rahmadewi et. al (2015) hubungan antara CRM dengan keputusan pembelian terletak pada keinginan-keinginan dan pilihan pelanggan atas suatu merek yang merupakan kedekatan pelanggan dengan penyedia jasa/produk. Kedekatan dan kepercayaan pelanggan akan suatu penyedia jasa/produk akan menciptakan kemauan pelanggan untuk menggunakan kembali dan bahkan meningkatkan loyalitas pelanggan terhadap penyedia jasa/produk. Teori penghubung antara CRM dengan keputusan pembelian dikutip dari Rangkuti (2002) yang mengatakan "Apabila pelanggan beranggapan bahwa penyedia jasa tertentu berbeda dengan pesaing. Pembeda keduanya adalah dari CRM yang akan melekat secara terus menerus sehingga dapat membentuk kesetiaan untuk terus menggunakan jasa tersebut". Hasil penelitian ini sama dengan hasil penelitian Lisdayanti (2017) yang menyatakan bahwa CRM berpengaruh secara positif dan signifikan terhadap keputusan pembelian.

\section{Pengaruh Kualitas Pelayanan Terhadap Keputusan Pembelian}

Hasil pengujian yang disajikan pada Tabel 4.10 menunjukkan kualitas pelayanan $\left(\mathrm{X}_{2}\right)$ dengan nilai $t_{\text {hitung }} 2,873>t_{\text {tabel }} 1,984$ dengan nilai signifikansi $0,000<0,05$, artinya kualitas pelayanan berpengaruh signifikan terhadap keputusan pembelian. Pengaruh dari kualitas pelayanan terhadap keputusan pembelian hasil analisis menunjukkan bahwa kualitas pelayanan berpengaruh positif dan signifikan terhadap keputusan pembelian. Hal ini menunjukkan bahwa semakin baik layanan yang diberikan oleh perusahaan terhadap para pelanggannya maka akan semakin baik juga persepsi pelanggan terhadap layanan yang diberikan oleh perusahaan. Sebagai pihak yang membeli dan mengkonsumsi produk/jasa, pelangganlah yang menilai tingkat kualitas pelayanan suatu perusahaan.

Menurut Tjiptono, (2004:145) kualitas pelayanan yang baik akan menciptakan kepuasan bagi konsumen. Hal tersebut akan memengaruhi proses pengambilan keputusan pembelian. Apabila konsumen merasa puas akan layanan yang diberikan oleh suatu perusahaan, mereka akan membeli ulang serta memberi rekomendasi kepada orang lain untuk membeli di tempat yang sama. PT Nusantara Surya Sakti yang bergerak dibidang otomotif menyediakan produk dengan kualitas pelayanan yang baik akan memicu konsumen untuk menjatuhkan pilihan di dealer NSS dari pada dealer lain. Sesuai dengan selogan NSS yaitu tercepat, termudah dan terpercaya yang diberikan oleh perusahaan dapat memengaruhi tindakan konsumen 
dalam pengambilan keputusan pembelian di PT. Nusantara Surya Sakti Sumbawa. Hasil penelitian ini sama dengan hasil penelitian yang dilakukan oleh Siow (2013) yang menyatakan bahwa kualitas pelayanan berpengaruh positif dan signifikan terhadap keputusan pembelian.

\section{Pengaruh Customer Relationship Management dan Kualitas Pelayanan Terhadap Keputusan Pembelian}

Berdasarkan hasil analisis data diketahui bahwa variabel customer relationship management dan kualitas pelayanan berpengaruh secara simultan terhadap keputusan pembelian.

Dalam memengaruhi keputusan pembelian, sebuah perusahaan harus dapat memberikan layanan terbaik kepada para konsumennya. Selain itu, membangun hubungan dengan pelanggan juga memiliki peran penting dalam sebuah perusahaan. Usaha dalam mendapatkan dan mempertahankan pelanggan memang tidaklah mudah. Oleh karena itu, perlu beberapa tahapan, mulai dari kesan pertama pelanggan sampai dengan memperoleh pelanggan yang setia. Cara memengaruhi keputusan pembelian konsumen, NSS harus terus berusaha meningkatkan customer relationship management serta kualitas pelayanan yang diberikan. Sehingga pelanggan akan merasa yakin untuk melakukan pembelian di NSS.

Adanya pengaruh positif dan signifikan variabel customer relationship management dan kualitas pelayanan ini juga didukung dengan hasil R Square pada Koefisien Determinasi sebesar $40 \%$. Hal ini mengindikasikan bahwa sebesar $40 \%$ variabel independen CRM dan kualitas pelayanan dapat memengaruhi keputusan pembelian, sedangkan sisanya $60 \%$ dipengaruhi oleh faktorfaktor lain diluar variabel yang digunakan dalam penelitian ini.

Faktor lain yang dapat memengaruhi keputusan pembelian antara lain: harga. Harga merupakan sejumlah uang yang dibebankan atas suatu produk/jasa, atau jumlah dari nilai yang ditukar konsumen atas manfaat-manfaat karena memiliki atau menggunakan produk/jasa tersebut. Harga juga memiliki manfaat yang besar terhadap tingkat kepuasan konsumen karena dengan harga yang terjangkau maka konsumen merasa puas sedangkan penetepan harga yang tidak sesuai akan berpengaruh pada konsumen. Hal ini menunjukkan bahwa harga menjadi salah satu pertimbangan konsumen dalam memutuskan akan membeli atau tidak suatu produk. Hasil penelitian yang menunjukkan bahwa harga berpengaruh terhadap keputusan pembelian dilakukan oleh Lotulung et al (2015).

\section{PENUTUP}

\section{Kesimpulan}

Berdasarkan analisis dalam penelitian dan pembahasan hasil penelitian yang telah dilakukan, maka dapat ditarik kesimpulan sebagai berikut:

1. Inklusi keuangan memberikan pengaruh positif dan signifikan terhadap kinerja UMKM. Hal ini menunjukan bahwa kinerja UMKM akan meningkat secara signifikan apabila pelaku UMKM terus meningkatkan inklusi keuangan.

2. Literasi keuangan memberikan pengaruh positif dan signifikan terhadap kinerja UMKM. Hal ini menunjukan bahwa kinerja UMKM akan meningkat secara signifikan apabila pelaku UMKM terus meningkatkan literasi keuangan

\section{Saran}

1. Bagi peneliti selanjutnya, diharapkan penelitian ini dapat menjadi refrensi dan masukan untuk menambah wawasan. Peneliti menyarankan untuk menambah jumlah variabel dan jumlah responden agar dapat memberikan informasi terbaru.

2. Bagi pelaku UMKM penelitian ini di harapkan dapat memberikan gambaran bagi pelaku UMKM maupun calon pengusaha dalam mengakses jasa layanan keuangan yang dapat dipergunakan untuk mendukung modal usaha dan keberlangsungan usaha.

3. Bagi Pemerintah, penelitian ini diharapkan dapat memberikan masukan dan menjadi bahan pertimbangan dalam menentukan kebijakan dan strategi ekonomi, khususnya kebijakan yang dapat mendukung perkembangan UMKM di Sumbawa.

\section{REFERENSI}

Akmal, Hariyatul dan Yogi Saputra. 2016. "Analisis Tingkat Literasi

Keuangan”. Dalam Jurnal Ekonomi dan Bisnis Islam, Vol. 1, No. 2, hlm. 235-244.

Anggraeni, Birawani Dewi. (2015). Pengaruh Tingkat Literasi Keuangan Pemilik Usaha Terhadap Pengelolaan Keuangan. Jurnal Vokasi Indonesia, Vol.3, No 1.

Aribawa, Dwitya. (2016). Pengaruh Literasi Keuangan Terhadap Kinerja Dan Keberlangsungan UMKM di Jawa Tengah.Jurnal Siasat Bisnis. Vol 20. No 1.

Anwar Muhadjir, Purwanto Eko, Suwaidi dan Anienda Mas.(2015). Tinjauan Deskripsi Keuangan Inklusi Pada Sentra Industri 
Kcil di Jawa Timur. Prosiding Seminar Nasional "research Month".

Badan Pusat Statistik Kabupaten Sumbawa.(2017). Kecamatan Moyo Utara.

Bank Indonesia.(2014). Booklet Keuangan Inklusif.Departemen Pengembangan Akses Keuangan dan UMKM.Bank Indonesia.

Bank Indonesia.(2014). "Kajian Ekonomi Dan Keuangan Regional Provinsi Nusa Tenggara Barat.Triwulan I 2014”. Bank Indonesia.

Bank Indonesia.(2016). Peraturan Presiden Republik Indonesia Nomor 82 Tahun 2016 Tentang Strategi Nasional Keuangan Inklusif. Bank Indonesia.

Chauvet Lisa and Jacolin Luc.(2015). Financial Inclusion and Firms Performance. $H A L$ archives-ouverts.

Chen, Haiyang \& Volpe, Ronald P. (1998). An Analysis of Personal Financial Literacy Among College Students. Financial Services Review 7(2): 107-128.

Dahmen, Pearl and Rodriguez Elieen. (2014).Financial Literacy and the Success of Small Businesses: An Observation from a Small Business Development Center.Numeracy, Advancing Education in Quantitative Literacy. Vol. 7 : Iss. 1, Article 3.

Dewi, Ditha Cahya. (2017). Analisis pengaruh financial inclusion terhadap pendapatan pengrajin rotan di Kecamatan Gatak Kabupaten Sukoharjo. Skripsi fakultas ekonomi dan bisnis islam institute agama islam negeri Surakarta.

Kaplan, Robert S dan Norton, David P. (2005). The balanced scorecard - Measures that drive performance. Harvard Business Review. 83(7). 172.

Latifiana Dwi. (2017).Studi Literasi Keuangan Pengelola Usaha Kecil Menengah (UKM).Universitas Sebelas Maret (UNS) Surakarta.

Mabyakto, Galang. (2017). Analisis tingkat literasi keuangan mahasiswa.Skripsi Fakultas
Ekonomi Universitas Sanata Dharma Yogyakarta.

Manurung, Jonni dan Adler HaymansManurung. (2009). Ekonomi Keuangan \& Kebijakan Moneter. Jakarta: Salemba Empat.

Nengsih, Nonia. (2015). Peran Perbankan Syariah Dalam Mengimplikasikan Keuangan Inklusif Di Indonesia. Jurnal Ekonomi. Volume 14. No 2. Hal 221-240

Nofianti, Henny.(2014). Dampak Pembiayaan Umkm Oleh Bank Perkreditan Rakyat Di Bali Terhadap Kinerja Umkm.Fakultas Ekonomi Universitas Udayana Bali, Indonesia

Otoritas Jasa Keuangan. (2016). "Survei Nasional Literasi Keuangan dan Inklusi Keuangan 2016".

Otoritas Jasa Keuangan. (2017). "Strategi Nasional Literasi Keuangan Nasional”. Jakarta.

Ratnawati. (2014). Tingkat Pendidikan dan Pengetahuan Literasi Keuanagan, Sustainability Usaha Sebagai Upaya Meningkatkan Kinerja Manajemen UKM. Jurnal Ilmiah. Vol 24. No 2.

Saiman, Leonardus. (2014). Kewirausahaan. Jakarta: Salemba Empat.

Sanusi, Anwar. (2011). Metode Penelitian Bisnis. Jakarta: Salemba Empat.

Setyani, Irmawati. (2013). Model Inklusi Keuangan Pada UMKM Berbasis Pedesaan.Jurnal of Economics and Policy. Vol 2. Hal 1-11.

Siregar, Syofian. (2017). Metode Penelitian Kuantitatif. Jakarta: Kencana

Steelyana, Evi. (2013). Perempuan dan Perbankan: Sebuah Tinjauan Tentang Peran Inklusi Keuangan Terhadap Pengusaha UMKM Perempuan di Indonesia. Jurnal The Winners. Vol 14. No 2. Hal 1-9.

Sugiyono.(2015). Metode Penelitian Kuantitatif, Kualitatif, dan $R \& D$. Bandung: Alfabeta.

Undang-Undang Republik Indonesia Nomor 20 Tahun 2008 tentang Usaha Mikro Kecil dan Menengah.

World Bank. (2016). Fintech And Financial Inclusion. World Bank Group 